\title{
Bioaerosol Concentrations and Size Distributions during the Autumn and Winter Seasons in an Industrial City of Central China
}

\author{
Ting Liu", L.-W. Antony Chen ${ }^{2 *}$, Mi Zhang ${ }^{3}$, John G. Watson ${ }^{3}$, Judith C. Chow ${ }^{3}$, Junji Cao ${ }^{4}$, \\ Hongyu Chen ${ }^{1}$, Wei Wang ${ }^{1}$, Jiaquan Zhang ${ }^{1}$, Changlin Zhan ${ }^{1}$, Hongxia Liu ${ }^{1}$, Jingru Zheng ${ }^{1}$, \\ Naiwen Chen ${ }^{5}$, Ruizhen Yao ${ }^{1}$, Wensheng Xiao ${ }^{1}$
}

${ }^{I}$ School of Environmental Science and Engineering, Hubei Key Laboratory of Mine Environmental Pollution Control and Remediation, Hubei Polytechnic University, Huangshi 435003, China

${ }^{2}$ Department of Environmental and Occupational Health, School of Public Health, University of Nevada Las Vegas, Las Vegas, NV 89154, USA

${ }^{3}$ Division of Atmospheric Sciences, Desert Research Institute, Reno, NV 89512, USA

${ }^{4}$ Key Laboratory of Aerosol Chemistry \& Physics (KLACP), Institute of Earth Environment, Chinese Academy of Sciences, Xi'an 710061, China

${ }^{5}$ School of Energy and Environment, City University of Hong Kong, Hong Kong 999077, China

\begin{abstract}
The ambient bioaerosols were measured in $\mathrm{PM}_{2.5}$ and $\mathrm{PM}_{10}$ samples taken in Huangshi City, Hubei Province, China, during autumn and winter from November 2017 to February 2018. Both the bioaerosol number concentration and size distribution $(0.37-16 \mu \mathrm{m})$ were obtained by direct fluorescent staining coupled with microscopic imaging. The bioaerosol number concentrations ranged from 0.05 to $3.4 \mathrm{\#} \mathrm{cm}^{-3}$ for $\mathrm{PM}_{2.5}$ and from 0.17 to $5.7 \mathrm{\#} \mathrm{cm}^{-3}$ for $\mathrm{PM}_{10}$, with averages of $0.90 \mathrm{\#} \mathrm{cm}^{-3}$ and $1.9 \mathrm{\#} \mathrm{cm}^{-3}$, respectively. In terms of particle number, the bioaerosols were dominated by fine particles $(0.37-2.5 \mu \mathrm{m}$ in diameter), with a larger proportion of submicron than supermicron particles. Assuming a unit density of $1 \mathrm{~g} \mathrm{~cm}^{-3}$ and a spherical shape for the particles, the mass abundances of the bioaerosols were estimated to be $2.4 \pm 1.9 \%$ and $4.8 \pm 3.2 \%$ of the $\mathrm{PM}_{2.5}$ and $\mathrm{PM}_{10}$, respectively, as measured by a nearby compliance monitor. Higher bioaerosol concentrations were observed in winter than autumn and on polluted than non-polluted days. During heavily polluted conditions, bioaerosols in the $\mathrm{PM}_{2.5}$ and $\mathrm{PM}_{10}$ were enriched by 6 and 3.7 times, respectively, compared to non-polluted days and contributed up to $15 \%$ of the $\mathrm{PM}_{10}$ mass. Rainfall and snowfall appeared to lower the bioaerosol levels. As enhanced emission controls on combustion and dust sources decrease PM levels in China, the bioaerosol fraction in measured PM concentrations will likely increase.
\end{abstract}

Keywords: Primary biological aerosol particles (PBAP); $\mathrm{PM}_{2.5} ; \mathrm{PM}_{10}$; Size distribution; Air quality; Fluorescence microscopy.

\section{INTRODUCTION}

Bioaerosols, also referred to as primary biological aerosol particles (PBAPs), include fur fibers, dandruff, skin fragments, plant fragments, pollen, spores, bacteria, algae, fungi, and viruses ranging in diameters from tens of nanometers to millimeters (Jaenicke, 2005). Bioaerosols are important because some PBAPs cause human, plant, and animal diseases (Douwes et al., 2003; Griffin, 2007) while

\footnotetext{
* Corresponding author.

Tel.: 1-702-895-1420

E-mail address: antony.chen@unlv.edu
}

others act as cloud condensation nuclei affecting cloud formation and precipitation (Hauspie and Pagezy, 2002; Heidi et al., 2003; Group, 2004; Rosenfeld et al., 2008). Recent studies suggest diverse bioaerosol concentrations and size distributions in both indoor and outdoor environments while calling for a better understanding of how bioaerosols co-vary with other air pollutants, especially $\mathrm{PM}_{2.5}$ and $\mathrm{PM}_{10}$ (airborne particulate matter [PM] with aerodynamic diameter $<2.5$ and $<10 \mu \mathrm{m}$, respectively), and their effects on climate and health (Wei et al., 2016; Huang et al., 2017; Xie et al., 2018; Zhai et al., 2018).

Poor air quality in China, particularly elevated $\mathrm{PM}_{2.5}$ during cold seasons, is often attributed to extensive coal combustion for heating coupled with unfavorable weather patterns (Cao et al., 2012; Huang et al., 2014; Fu and 
Chen, 2017). Although $\mathrm{PM}_{2.5}$ chemical compositions have been studied and used for source apportionment (Henry et al., 1984; Watson et al., 2008, 2016; Cheng et al., 2018), bioaerosol contributions to $\mathrm{PM}_{2.5}$ are rarely assessed. Several recent studies examined the spatial and temporal variability of bioaerosol concentrations, size distributions, and speciation in China (Cao et al., 2014; Gao et al., 2015; Li et al., 2015; Dong et al., 2016; Wei et al., 2016). Higher bioaerosol concentrations were reported on polluted than on non-polluted days. Xie et al. (2018) found a positive relationship between air quality index (AQI) and bioaerosol concentrations. Most of these studies were conducted in heavily populated megacities of northern China, such as Beijing, Xi' an, and Qingdao (Cao et al., 2014; Wei et al., 2016; Dong et al., 2016; Xie et al., 2018). Bioaerosol characteristics may differ in smaller cities and in centralsouthern China, owning to different vegetation, land use, and climate conditions.

Huangshi, a medium-size city with an area of $4,583 \mathrm{~km}^{2}$ and a population of $\sim 2.5$ million, is located $\sim 90 \mathrm{~km}$ southwest of Wuhan in central China. It features a subtropical continental monsoon climate, with a mean annual temperature of $17^{\circ} \mathrm{C}$ and precipitation of $\sim 1400 \mathrm{~mm}$. The diverse vegetation coupled with mild temperatures and high relative humidity facilitates bioaerosol production. Huangshi is an important industrial source of raw materials with high energy consumption and the accompanying environmental pollution (Liu et al., 2017). Affected by local industries, particularly coal-based ore smelters, and intrusion of regional polluted air, poor air quality often occurs during autumn and winter. Average $\mathrm{PM}_{2.5}$ concentrations for the two seasons have exceeded $100 \mu \mathrm{g} \mathrm{m}^{-3}$ with $\sim 20 \%$ from organic carbon (OC) (Zhan et al., 2017). Based on the EC-tracer analysis, Zhan et al. (2017) concluded that a substantial fraction of OC originated from bioaerosols and/or secondary organic carbon (SOC), but they were not able to distinguish between the two. Average OC in $\mathrm{PM}_{10}$ was $\sim 5 \mu \mathrm{g} \mathrm{m}^{-3}$ higher than in $\mathrm{PM}_{2.5}$ (Zhan et al., 2017) and the difference may be due to bioaerosols such as fungal spores, pollen, and vegetative detritus (Edgerton et al., 2009).

Chen et al. (2019) demonstrated the practicality of using a direct-staining (DS) technique, coupled with epifluorescence microscopy (FM), to quantify bioaerosols collected on filters. The DS-FM method measures bioaerosol number concentration and size distribution, from which the bioaerosol mass can be estimated. Compared to culturebased methods, fluorescence methods detect bioaerosols in viable, non-viable, and viable but non-culturable states ( $\mathrm{Li}$ and Huang, 2006; Chi and Li, 2007; Li et al., 2011). DSFM is also more cost-effective than online monitoring with fluorescence analyzers, such as the Waveband Integrated Bioaerosol Sensor (WIBS) and Ultraviolet Aerodynamic Particle Sizer (UV-APS). This study applies the DS-FM method to $\mathrm{PM}_{2.5}$ and $\mathrm{PM}_{10}$ filter samples collected in Huangshi. The concentrations and size distributions of bioaerosols are examined. Results from this work further our understanding of bioaerosol contributions to PM and offer insights to the regional air pollution management.

\section{METHODS}

\section{Sampling Site and Methods}

The sampling site $\left(30^{\circ} 12^{\prime} 35.71^{\prime \prime} \mathrm{N}, 115^{\circ} 01^{\prime} 30.75^{\prime \prime} \mathrm{E}\right)$ was on the rooftop of a five-story building (about $15 \mathrm{~m} \mathrm{AGL)}$ at the Hebei Polytechnic University (HBPU) campus in central Huangshi (Fig. 1). This site is surrounded by trees, greenbelts, and a stadium and is $\sim 400 \mathrm{~m}$ from major highways with no nearby industrial activities. Ambient $\mathrm{PM}_{2.5}$ and $\mathrm{PM}_{10}$ samples were acquired daily between November 4, 2017, and February 10, 2018, using a pair of MiniVol samplers (Airmetrics, Springfield, OR, USA) equipped with size-selective inlet sampling at $\sim 5 \mathrm{~L} \mathrm{~min}^{-1}$. Sampling started at 13:00 LST and lasted for 5-8 hours. Particles were collected onto $47-\mathrm{mm}$ diameter black polycarbonate filters $(0.2 \mu \mathrm{m}$ pore size, PCTE; Whatman, Little Chalfont, $\mathrm{UK}$ ) as these provide the lowest background for DS-FM.

Hourly $\mathrm{PM}_{2.5}$ and $\mathrm{PM}_{10}$ mass concentrations were measured using a Tapered Element Oscillating Microbalance (1405 TEOM ${ }^{\mathrm{TM}}$; Thermal Fisher Scientific, Waltham, MA, USA) located $\sim 80 \mathrm{~m}$ from the HBPU site (see Fig. 1), as part of the Ministry of Ecology and Environment's compliance network to determine Air Quality Index (AQI). According to China's "Technical Regulation on Ambient Air Quality Index (HJ633-2012)," the AQI value from $\mathrm{PM}_{2.5}$ is used to categorize air pollution. One of the six air quality levels - good (0-50), moderate (51-100), lightly polluted (101-150), moderately polluted (151-200), heavily polluted (201-300), and severely polluted ( $>300)$ — was assigned to each monitoring day. Days with AQI values below 100 (good and moderate) were considered as non-polluted days.

Local meteorological parameters such as wind speed and precipitation were obtained from the China Weather Network (http://www.weather.com.cn/weather1d/1012006 01.shtml).

\section{Bioaerosol Particle Detection}

Bioaerosols were measured using a fluorescence microscope after staining with 4',6-diamidino-2-phenylindole dihydrochloride (DAPI) following the DS-FM protocol as described in Chen et al. (2019). Briefly, a 13-mm diameter disc was removed from each polycarbonate filter sample and placed with the deposit-side up onto a drop of DAPI working solution $\left(20 \mu \mathrm{g} \mathrm{mL}^{-1}\right)$. It was incubated at room temperature in the dark for 20 minutes while the stain permeated through the filter to interact with the bioaerosols (Griffin et al., 2001; Prussin et al., 2015). A coverslip was then mounted on the stained sample with a water-soluble, anti-fading adhesive (Mounting Medium; Solarbio, Beijing, China) and stored below $4^{\circ} \mathrm{C}$ before epifluorescence investigation. DS-FM differs from the extraction-staining fluorescence microscopy (ES-FM) method (Cao et al., 2014; Dong et al., 2016; Wei et al., 2016; Xie et al., 2018) in that the latter stains particles in a liquid after they are extracted from filter samples. The stained particles are then re-deposited onto polycarbonate filters for FM analysis.

The prepared sample slides were examined on a fluorescence microscope (DM2500; Leica, Germany) equipped with a Charge Coupled Device (CCD) camera 


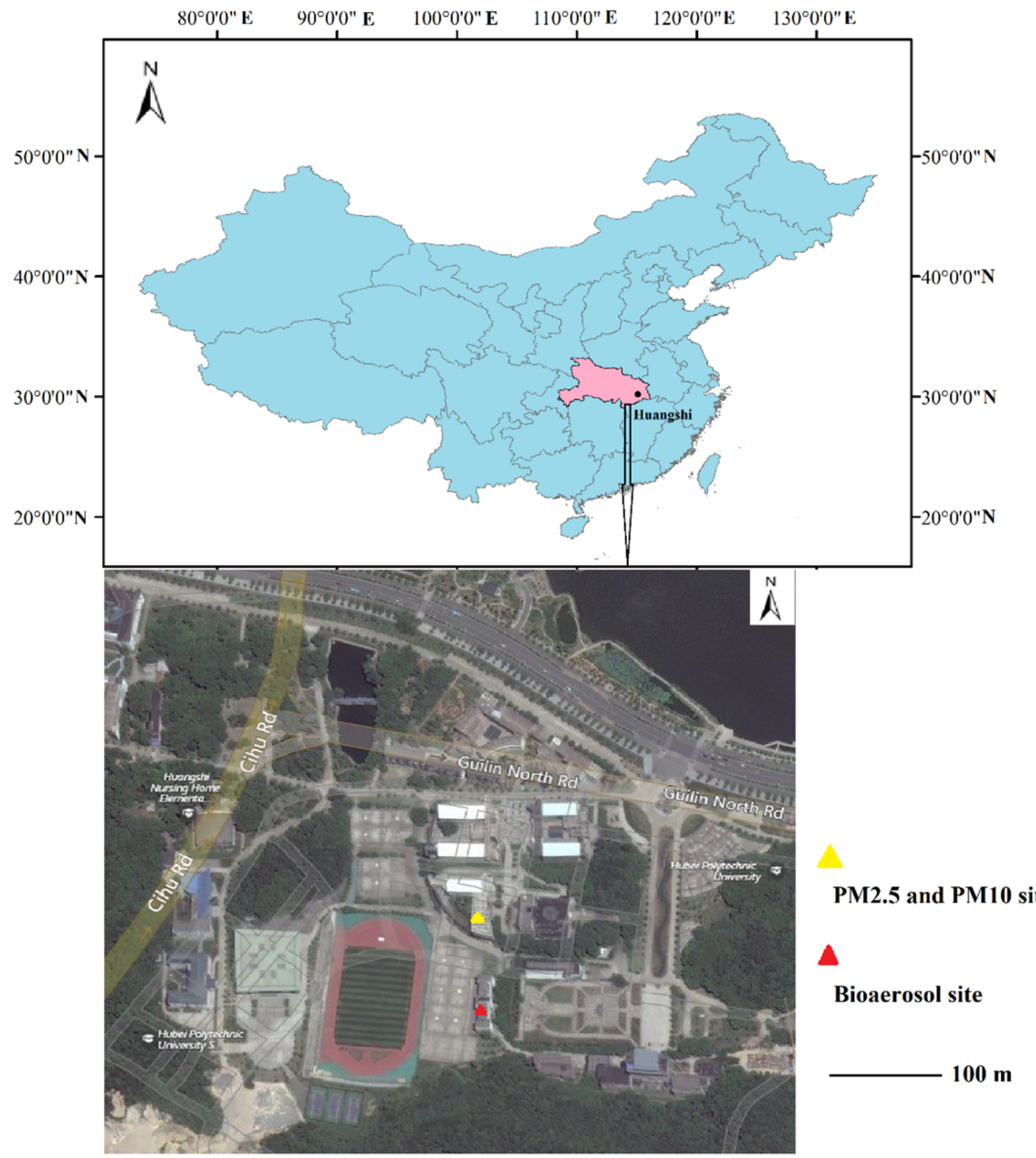

Fig. 1. Bioaerosol monitoring site and the nearby $(\sim 80 \mathrm{~m})$ air quality monitoring station at the Hubei Polytechnic University (HBPU), Huangshi, China.

(DFC450 C; Leica, Germany) and a filter cube containing a 350/50 band pass (BP) excitation filter, a $400 \mathrm{~nm}$ dichromatic mirror, and a 460/50 BP emission filter. The DAPI-DNA coupling produces a bright blue fluorescence at $\sim 460 \mathrm{~nm}$ when excited with $365 \mathrm{~nm}$ light (Porter and Feig, 1980). Under a 400× magnification, about 30 images of view $\left(0.218 \times 0.163 \mathrm{~mm}^{2}, 2560 \times 1920\right.$ pixels $)$ were captured along a filter dissection to represent the entire $13-\mathrm{mm}$ diameter deposit area.

Controls were prepared from a subset of exposed filters in the same way as the samples except for staining with DAPI. Fluorescing particles were not detected on the controls (see examples in Fig. S1 of the supplementary information). Though non-biological particles such as those containing polycyclic aromatic hydrocarbons (PAHs) auto-fluoresce in the emission region of 440-470 nm (Pan, 2015), the autofluorescence may be too weak to be distinguished from the background of polycarbonate filter.

\section{Quantification of Bioaerosol Concentration and Size Distribution}

Using the Image $J^{\circledR}$ software, the total number and area of bioaerosol particles on each fluorescence image were calculated automatically. The images were converted to binary (black-and-white) pictures with the fluorescent particles, a surrogate for bioaerosols, in black against a white background. The thresholding between particles and background was accomplished with the "Triangle" algorithm 
(Zack et al., 1977; Seo et al., 2014). Particles smaller than 15 pixels were excluded to suppress false positives. Image $J^{\circledR}$ reported the particle number in the image and the projected area $\left(A_{p}\right)$ of each individual particle, from which the equivalent projected area diameter $\left(D_{e q, A}\right)$ was calculated:

$$
D_{e q, A}=2\left(\frac{A_{p}}{\pi}\right)^{1 / 2}
$$

The cut-off $D_{e q, A}$ was $0.37 \mu \mathrm{m}$, corresponding to 15 pixels, which should be sufficient to detect most bacteria, fungal spores, and other major mass-contributing bioaerosol classes. The automatic bioaerosol counts were verified by manual counting for selected samples. Bioaerosol number concentration $\left(\# \mathrm{~cm}^{-2}\right)$ was determined from the average particle counts over the 30 fluorescence images taken for each sample, divided by the image area $\left(0.218 \times 0.163 \mathrm{~mm}^{2}\right)$, with the standard error representing the uncertainty.

To estimate bioaerosol mass, particle volume $(V)$ and density $(\rho)$ are required. The first-order approximation assumes spherical particles, thus:

$$
V=\frac{\pi}{6}\left(D_{e q, A}\right)^{3}
$$

Particle density may depend on the bioaerosol type, but an assumption of $1 \mathrm{~g} \mathrm{~cm}^{-3}$ (Matthias-Maser and Jaenicke, 2000; Chow et al., 2015) was used in this study for all bioaerosol particles. The bioaerosol number and mass concentrations were converted to $\mathrm{Hcm}^{-3}$ and $\mu \mathrm{g} \mathrm{m}^{-3}$, respectively, using the MiniVol sampling time and flow rate. Errors from the bioaerosol count and flow rate were propagated to yield the measurement uncertainty. Excel 2013 and SPSS 19.0 software were used to statistically analyze the experimental data.

\section{RESULTS AND DISCUSSION}

\section{Bioaerosol Concentrations and Size Distribution}

A total of 51 pairs of $\mathrm{PM}_{2.5} / \mathrm{PM}_{10}$ samples were collected. Bioaerosol number concentrations ranged from 0.05 to $3.37 \#_{\mathrm{cm}^{-3}}$ for $\mathrm{PM}_{2.5}$ and from 0.17 to $5.73 \mathrm{\#} \mathrm{cm}^{-3}$ for $\mathrm{PM}_{10}$ (Fig. 2), with averages of $0.90 \# \mathrm{~cm}^{-3}$ and $1.86 \mathrm{H} \mathrm{cm}^{-3}$, respectively. Taking November as autumn and December to January as winter, the concentrations varied significantly by season with higher values found in winter $\left(1.04{\mathrm{\#} \mathrm{cm}^{-3}}^{-3}\right.$ for $\mathrm{PM}_{2.5}$ and $2.16 \# \mathrm{~cm}^{-3}$ for $\mathrm{PM}_{10}$ ) than during autumn $\left(0.60 \mathrm{\#} \mathrm{cm}^{-3}\right.$ for $\mathrm{PM}_{2.5}$ and $1.25 \mathrm{\#} \mathrm{cm}^{-3}$ for $\left.\mathrm{PM}_{10}\right)$. Xie et al. (2018) and Dong et al. (2016) observed similar seasonal differences in Xi' an and Qingdao, China, respectively. They attributed the high winter bioaerosol levels to stagnant weather conditions, high PM levels, and hazy days. In Huangshi, severe haze pollution was also observed more frequently in winter.

With respect to the particle size-number distribution, bioaerosols were dominated by fine particles $0.37-2.5 \mu \mathrm{m}$ in diameter (Fig. 3). Image analysis showed that coarse particles $\left(D_{e q, A}>2.5 \mu \mathrm{m}\right)$ accounted for $2.6 \%$ and $6.5 \%$ of bioaerosol numbers in $\mathrm{PM}_{2.5}$ and $\mathrm{PM}_{10}$ samples, respectively. The small fraction of coarse particles in $\mathrm{PM}_{2.5}$ samples reflects the imperfect MiniVol size-selective inlet that passes some coarse particles. Bioaerosols with diameters smaller than $1 \mu \mathrm{m}$ were classified as prokaryotes (e.g., bacteria) and viruses, while supermicrometer particles were classified as eukaryotes (e.g., fungal spores, pollen, and organic debris) (Mayol et al., 2014). The proportions of prokaryotes were $68.7 \%$ among $\mathrm{PM}_{2.5}$ and $59.5 \%$ among $\mathrm{PM}_{10}$ bioaerosols, and the proportions of eukaryotes were lower with $31.3 \%$ among $\mathrm{PM}_{2.5}$ and $40.5 \%$ among $\mathrm{PM}_{10}$ bioaerosols.

If determined from the difference of bioaerosol concentrations between $\mathrm{PM}_{10}$ and $\mathrm{PM}_{2.5}$ samples (i.e., 1.86 minus $0.90 \mathrm{\#} \mathrm{cm}^{-3}$ ), coarse bioaerosols would account for $0.96 \mathrm{~A} \mathrm{~cm}^{-3}$ or $51.6 \%$ of the $\mathrm{PM}_{10}$ bioaerosol numbers,

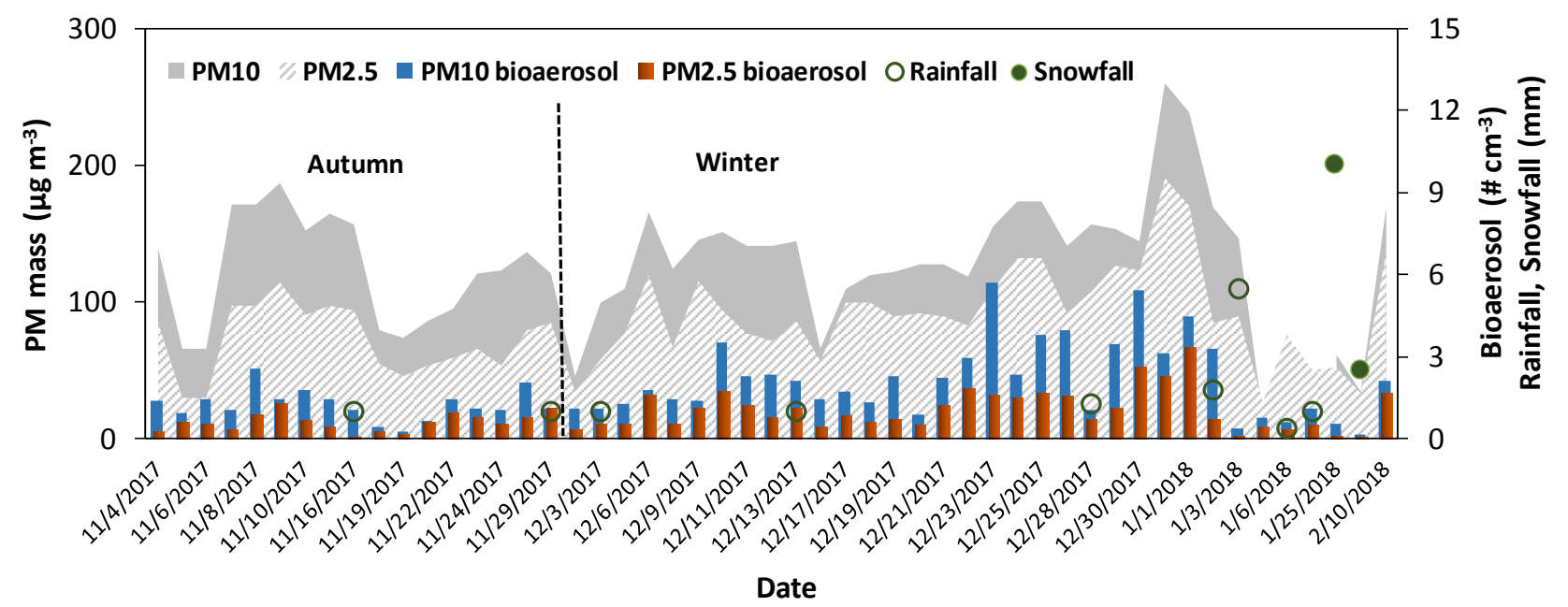

Fig. 2. Day-to-day variability in $\mathrm{PM}_{10}$ and $\mathrm{PM}_{2.5}$ mass (from TEOM compliance monitors) and bioaerosol number concentrations from November 4, 2017, to February 10, 2018, in Huangshi, China. $\mathrm{PM}_{2.5}$ concentration exceeded $\mathrm{PM}_{10}$ on January 5 and 7, 2018, likely due to interference from heavy rain. 


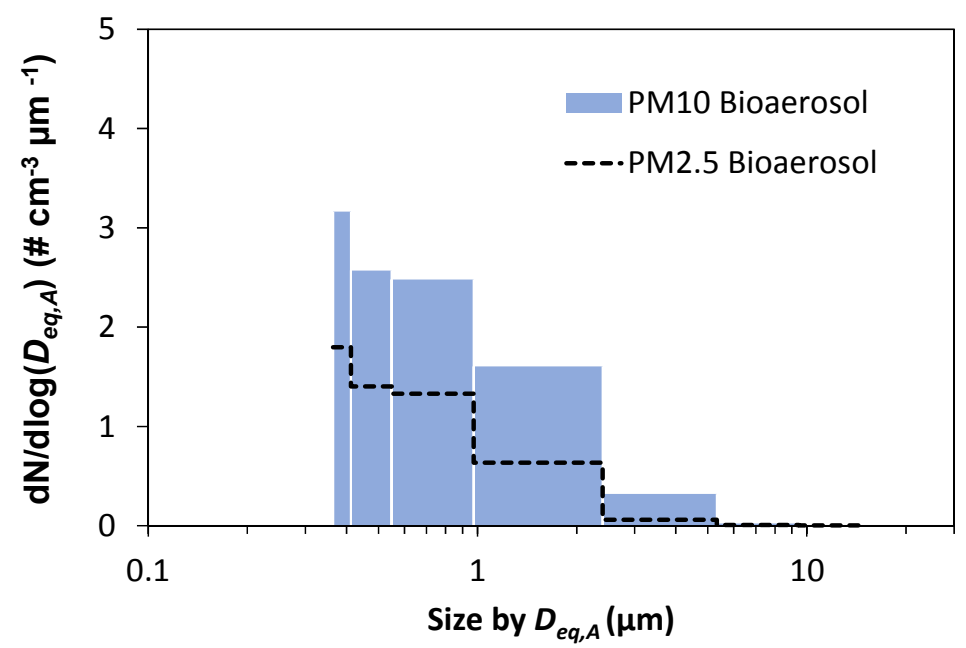

Fig. 3. Average number-size distribution of bioaerosol samples measured by DS-FM. Particles were counted by 7 size bins $(0.37-0.42,0.42-0.56,0.56-1,1-2.5,2.5-5.6,5.6-10$, and $10-16 \mu \mathrm{m})$ and averaged over all samples.

much larger than the $6.5 \%$ number fraction inferred solely from the image analysis of $\mathrm{PM}_{10}$ samples. The contrast suggests that substantial fine bioaerosol particles might have been attached to other coarse particles (e.g., fugitive dust) and only captured in $\mathrm{PM}_{10}$ samples. Similar phenomena were reported during dust episodes (Yeo and Kim, 2002; Hallar et al., 2011).

The reconstructed bioaerosol mass from Eq. (2) exhibits a dominant contribution from supermicrometer particles (Fig. 4). As show in Fig. 2, $\mathrm{PM}_{2.5}$ mass ranged from 27 to $190 \mu \mathrm{g} \mathrm{m}^{-3}$ with an average of $85.7 \mu \mathrm{g} \mathrm{m}^{-3}$ while $\mathrm{PM}_{10}$ mass ranged from 34 to $260 \mu \mathrm{g} \mathrm{m}^{-3}$ with an average of $129 \mu \mathrm{g} \mathrm{m}^{-3}$. The bioaerosol component, on average, accounted for $2.1 \mu \mathrm{g} \mathrm{m}^{-3}(2.4 \pm 1.9 \%)$ of $\mathrm{PM}_{2.5}$ mass and $6.3 \mu \mathrm{g} \mathrm{m}^{-3}(4.8 \pm$ $3.2 \%$ ) of $\mathrm{PM}_{10}$ mass with the highest mass fractions being $10 \%$ for $\mathrm{PM}_{2.5}$ (December 13,2017 ) and $14 \%$ for $\mathrm{PM}_{10}$ (December 18, 2017).

The summed mass of bioaerosols with $D_{e q, A}<2.5 \mu \mathrm{m}$ on $\mathrm{PM}_{10}$ sample images only accounts for $1.8 \pm 1.0 \%$ of $\mathrm{PM}_{2.5}$ mass, lower than the $2.4 \pm 1.9 \%$ reconstructed from $\mathrm{PM}_{2.5}$ sample images by combining bioaerosols of all sizes. On the other hand, coarse bioaerosols $>2.5 \mu \mathrm{m} D_{e q, A}$ would account for $13.5 \pm 15.5 \%$ of $\mathrm{PM}_{2.5-10}$ determined from the difference of $\mathrm{PM}_{10}$ and $\mathrm{PM}_{2.5}$ mass. The bioaerosol components were more substantial in coarse than fine PM.

\section{Relationships of Bioaerosol, PM, and Meteorological Conditions}

Temperature, relative humidity, wind speed, and ambient PM may influence bioaerosol concentrations. $\mathrm{PM}_{2.5}$ and $\mathrm{PM}_{10}$ mass were found to significantly correlate with the bioaerosol numbers (Table 1), consistent with previous research (Haas et al., 2013; Alghamdi et al., 2014; Xie et al., 2018). This suggests that bioaerosols and PM are impacted by similar factors. Coarse particles can act as carriers for microorganisms, and the increasing quantity of PM offers more surface area on which microbes can adhere (Jeon et al., 2011; Xie et al., 2018). On the other hand, ultrafine particles $(<100 \mathrm{~nm})$, including soot particles $(30-$
$40 \mathrm{~nm}$ ), may adhere to bioaerosols.

Daily mean temperatures varied from 0 to $23^{\circ} \mathrm{C}$ and daily mean wind speeds varied from 0.84 to $2.88 \mathrm{~m} \mathrm{~s}^{-1}$ throughout the monitoring period. Neither of them was correlated with bioaerosol levels. Relative humidity was negatively correlated with bioaerosol concentrations $(p<$ $0.05)$. High relative humidity mainly occurred on rainy and snowy days (Fig. 2), while bioaerosol concentrations during and after the precipitation decreased due to scavenging ( $\mathrm{Li}$ et al., 2017; Xie et al., 2018).

For example, through a prolonged rainfall from January 1 to January $3,2018, \mathrm{PM}_{2.5}$ concentrations were reduced from 170 to $89 \mu \mathrm{g} \mathrm{m}^{-3}$ and $\mathrm{PM}_{10}$ concentrations decreased from 239 to $147 \mu \mathrm{g} \mathrm{m}^{-3}$ while bioaerosol number concentrations decreased from 3.37 to $0.10 \mathrm{\#} \mathrm{cm}^{-3}$ in $\mathrm{PM}_{2.5}$ and from 4.48 to $0.41 \mathrm{\#} \mathrm{cm}^{-3}$ in $\mathrm{PM}_{10}$. A similar situation was observed for the January 25-26, 2018 snowfall period with low bioaerosol number concentrations (i.e., $0.05-0.09 \#^{-3}$ for $\mathrm{PM}_{2.5}$ and $0.17-0.52 \mathrm{H} \mathrm{cm}^{-3}$ for $\mathrm{PM}_{10}$ ) observed after the snow. By contrast, some studies reported higher bioaerosol levels after precipitation, particularly during the spring-summer blooming seasons (Huffman et al., 2013; Kang et al., 2015; Rathnayake et al., 2017).

\section{Bioaerosol versus Air Quality Levels}

Based on the AQI, there were 3 good days, 14 moderate days, 27 lightly polluted days, 5 moderately polluted days, and 2 heavily polluted days during the sampling period. Table 2 presents bioaerosol number and PM mass concentrations by AQI level. Average bioaerosol concentrations for non-polluted days were $0.47 \pm 0.24{\mathrm{\#} \mathrm{cm}^{-3}}^{-3}$ for $\mathrm{PM}_{2.5}$ and $1.02 \pm 0.53 \# \mathrm{~cm}^{-3}$ for $\mathrm{PM}_{10}$ and were significantly different from those for the heavily polluted days ( $t$-test: $p=0.002$ ). Average bioaerosol concentrations for moderately and heavily polluted days were 3.6-6 times higher for $\mathrm{PM}_{2.5}$ and 3.3-3.7 times higher for $\mathrm{PM}_{10}$ as compared with non-polluted days. There was no appreciable difference in the bioaerosol size distributions among different air quality levels. 


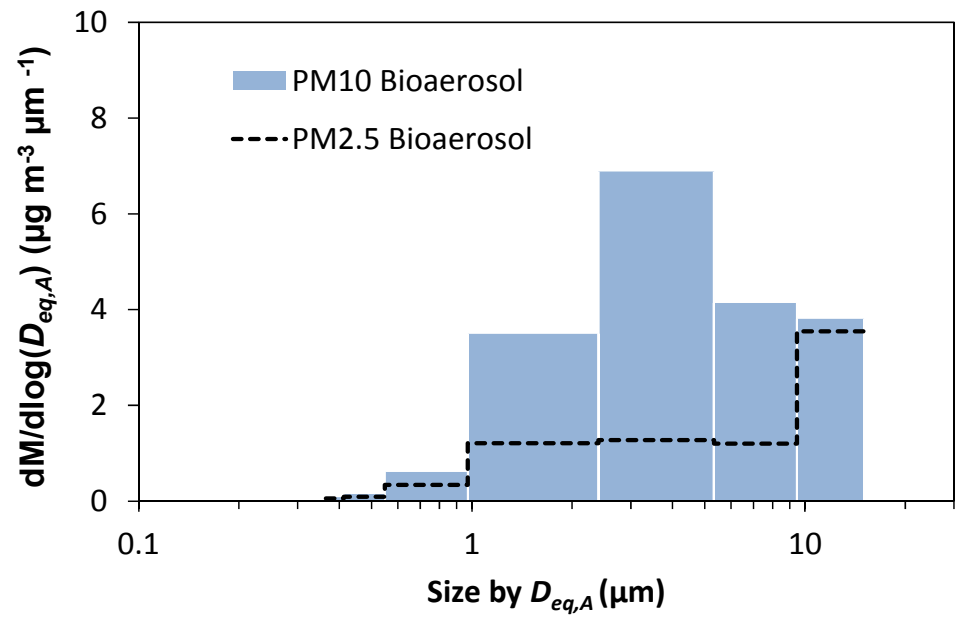

Fig. 4. Average mass-size distribution of $\mathrm{PM}_{2.5}$ and $\mathrm{PM}_{10}$ bioaerosols by DS-FM. Particle mass (M) was calculated for 7 size bins between 0.37 and $16 \mu \mathrm{m}$ in diameter $(0.37-0.42,0.42-0.56,0.56-1,1-2.5,2.5-5.6,5.6-10$, and $10-16 \mu \mathrm{m})$ and averaged over all samples.

Table 1. Spearman correlation coefficients between the bioaerosol concentrations and environmental factors for all sampling days.

\begin{tabular}{lllll}
\hline & $\mathrm{PM}_{2.5}{ }^{\mathrm{c}}$ & Temperature & $\mathrm{RH}^{\mathrm{e}}$ & Wind Speed $^{\mathrm{g}}$ \\
\hline $\mathrm{PM}_{2.5}$ Bioaerosols $^{\mathrm{a}}$ & $0.627^{* *}$ & 0.180 & $-0.463^{* *}$ & 0.124 \\
& $\mathrm{PM}_{10}{ }^{\mathrm{d}}$ & Temperature & $\mathrm{RH}^{\mathrm{f}}$ & Wind Speed $^{\mathrm{g}}$ \\
$\mathrm{PM}_{10}$ Bioaerosols $^{\mathrm{b}}$ & $0.582^{* *}$ & 0.178 & $-0.434^{*}$ & 0.094 \\
\hline
\end{tabular}

a bioaerosols of $\mathrm{PM}_{2.5}\left(\# \mathrm{~cm}^{-3}\right)$.

${ }^{\mathrm{b}}$ bioaerosols of $\mathrm{PM}_{10}\left(\# \mathrm{~cm}^{-3}\right)$.

${ }^{c} \mathrm{PM}_{2.5}$ mass $\left(\mu \mathrm{g} \mathrm{m}^{-3}\right)$.

${ }^{\mathrm{d}} \mathrm{PM}_{10}$ mass $\left(\mu \mathrm{g} \mathrm{m}^{-3}\right)$.

${ }^{\mathrm{e}}$ The daily mean temperature $\left({ }^{\circ} \mathrm{C}\right)$.

${ }^{\mathrm{f}}$ The daily mean relative humidity (\%).

$\mathrm{g}$ The daily mean wind speed $\left(\mathrm{m} \mathrm{sec}^{-1}\right)$.

${ }^{* *} \mathrm{p}<0.01$ (2-tailed).

* $\mathrm{p}<0.05$ (2-tailed).

Table 2. Summary of bioaerosol and PM mass concentrations by air quality level in Huangshi, China (November 4, 2017February 10, 2018).

\begin{tabular}{|c|c|c|c|c|c|}
\hline Air quality level $^{\mathrm{a}}$ & $\mathrm{N}^{\mathrm{b}}$ & $\mathrm{PM}_{2.5}\left(\mu \mathrm{g} \mathrm{m}^{-3}\right)$ & $\mathrm{PM}_{10}\left(\mu \mathrm{g} \mathrm{m}^{-3}\right)$ & $\mathrm{PM}_{2.5}$ Bioaerosol $\left(\# \mathrm{~cm}^{-3}\right)$ & $\mathrm{PM}_{10}$ Bioaerosol $\left(\# \mathrm{~cm}^{-3}\right)$ \\
\hline Good & 3 & $31 \pm 4$ & $32 \pm 15$ & $0.26 \pm 0.19$ & $0.70 \pm 0.49$ \\
\hline Moderate & 14 & $54 \pm 12$ & $92 \pm 27$ & $0.52 \pm 0.23$ & $1.09 \pm 0.53$ \\
\hline Lightly polluted & 27 & $96 \pm 18$ & $140 \pm 26$ & $0.88 \pm 0.51$ & $1.96 \pm 1.16$ \\
\hline Moderately polluted & 5 & $127 \pm 5$ & $162 \pm 13$ & $1.71 \pm 0.54$ & $3.36 \pm 1.40$ \\
\hline Heavily polluted & 2 & $180 \pm 14$ & $250 \pm 15$ & $2.84 \pm 0.75$ & $3.81 \pm 0.95$ \\
\hline
\end{tabular}

${ }^{\mathrm{a}}$ Air quality levels were categorized by AQI: Good (0-50), Moderate (51-100), Lightly polluted (101-150), Moderately polluted (151-200), Heavily polluted (201-300), and Severely polluted (>300). ${ }^{\mathrm{b}}$ Number of days for each air quality level.

AQI values were consistently above 100 and exceeded 200 (i.e., polluted) during the December 21, 2017-January 1, 2018 period with $\mathrm{PM}_{10}$ bioaerosol numbers $>2.25 \mathrm{\#} \mathrm{cm}^{-3}$, except on December 28, 2017 (1.08 \# $\left.\mathrm{cm}^{-3}\right)$, when precipitation of $\sim 1.3 \mathrm{~mm}$ occurred (Fig. 2). Elevated bioaerosol concentrations (2.6 $\# \mathrm{~cm}^{-3}$ for $\mathrm{PM}_{2.5}$ and $5.4 \# \mathrm{~cm}^{-3}$ for $\mathrm{PM}_{10}$ ), $\mathrm{PM}_{2.5}$ $\left(123 \mu \mathrm{g} \mathrm{m}^{-3}\right)$, and $\mathrm{PM}_{10}\left(144 \mu \mathrm{g} \mathrm{m}^{-3}\right)$ returned on December 30,2017 , right after the precipitation. The haze episode on December 30, 2017 covered part of Hubei Province (e.g., Wuhan and Huangshi) while also affecting nearby Anhui and Jiangshu Provinces. Back trajectory analysis (Fig. S2) reveals possible transport of polluted air masses from northern China. Bioaerosols contributed to $\sim 10 \%$ of $\mathrm{PM}_{10}$ mass during the episode.

In an urban environment such as Huangshi, conditions that engender high PM episodes, such as stagnation and shallow boundary layers, might also lead to the accumulation of bioaerosols, while precipitation would lower bioaerosol and other PM components simultaneously. It is noteworthy that bioaerosol concentrations did not always coincide with 
the deteriorating air quality. The highest $\mathrm{PM}_{10}$ bioaerosol concentration, $5.73 \mathrm{\#} \mathrm{cm}^{-3}$, was found on December 23, 2017, with an AQI of 144 (i.e., lightly polluted). Xie et al. (2018) reported the highest bioaerosol levels under the moderately polluted condition, whereas Wei et al. (2016) found that upon the occurrence of haze the number concentration of fluorescent particles ascended briefly, and then started to decrease as the haze progressed over time during a short monitoring period. The differences in source and formation mechanism between secondary aerosol and bioaerosols may explain their distinct temporal trends during the pollution episodes.

Table 3 compares the bioaerosol concentrations of polluted days. The average $\mathrm{PM}_{10}$ bioaerosol concentration in this study was 3-4 times higher than those measured in Beijing, Xi'an, and Qingdao. The Xi'an and Qingdao bioaerosols were measured using the ES-FM method with DAPI stain. ES-FM likely yields lower bioaerosol counts than DS-FM because of particle losses during the wash-off and re-deposition steps (Chen et al., 2019). Beijing's bioaerosols were quantified by UV-APS, though real-time auto-fluorescence methods including UV-APS and WIBS are known to underestimate bioaerosol counts as not every bioaerosol particle fluoresces under the experimental conditions (Huffman et al., 2010; Després et al., 2012). Different analytical methods partly explain the higher bioaerosol concentrations measured in this study. Other factors include different climate conditions among these cities.

\section{CONCLUSIONS}

The DS-FM method was applied to quantify not only the bioaerosol number concentration but also the size distribution. Higher concentrations were observed in winter than autumn and on polluted than non-polluted days. However, these levels did not peak at the climax of haze episodes, implying different sources and/or subtle interactions between the bioaerosols and the PM. The results also confirm the important role of precipitation in removing bioaerosols. The bioaerosol number concentration was higher in the $\mathrm{PM}_{2.5}$ fraction, but the mass concentration was higher in the $\mathrm{PM}_{2.5-10}$ fraction. Bioaerosols contributed substantially to the mass of airborne particles in Huangshi, especially on polluted days. As a result of enhanced emission controls that have been reducing PM from combustion and dust sources in China, bioaerosols are expected to constitute a growing fraction of measured PM concentrations. Investigations of bioaerosol contributions to air pollution should be continued and extended to other regions of China.

\section{ACKNOWLEDGMENTS}

The authors appreciate financial support from the Research Project of Hubei Provincial Department of Education (D20184502), the Hubei Universities of Outstanding Young Scientific and Technological Innovation Team Plans (T201729), and the Special Scientific Research Funds for National Basic Research Program of China (2013FY112700).

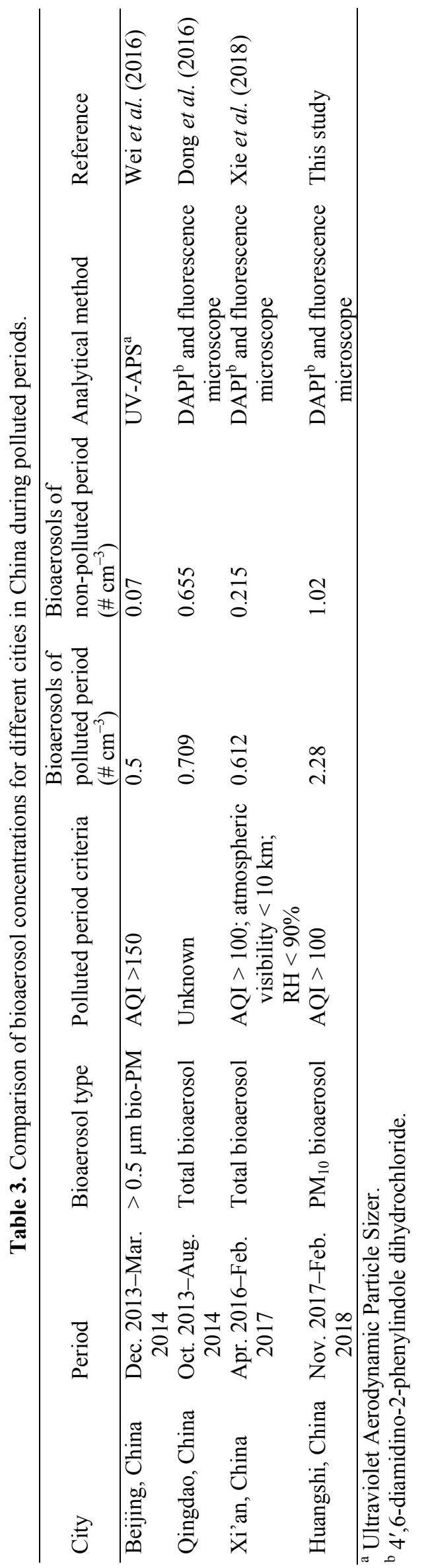


The University of Nevada, Las Vegas, and Desert Research Institute provided additional financial support for their participants.

\section{SUPPLEMENTARY MATERIAL}

Supplementary data associated with this article can be found in the online version at http://www.aaqr.org.

\section{REFERENCES}

Alghamdi, M.A., Shamy, M., Redal, M.A., Khoder, M., Awad, A.H. and Elserougy, S. (2014). Microorganisms associated particulate matter: A preliminary study. Sci. Total Environ. 479-480: 109-116.

Bauer, H., Claeys, M., Vermeylen, R., Schueller, E., Weinke, G., Berger, A. and Puxbaum, H. (2008). Arabitol and mannitol as tracers for the quantification of airborne fungal spores. Atmos. Environ. 42: 588-593.

Burge, H.A. (1995). Bioaerosol investigations. In Bioaerosols, Burge, H.A. (Ed.), Lewis Publishers, Boca Raton, FL, USA, p. 13.

Buser, M.D., Parnell, C.B., Shaw, B.W. and Lacey, R.E. (2007). Particulate matter sampler errors due to the interaction of particle size and sampler performance characteristics: Ambient $\mathrm{PM}_{2.5}$ samplers. Trans. ASABE 50: 241-254.

Cao, C., Jiang, W., Wang, B., Fang, J., Lang, J., Tian, G., Jiang, J. and Zhu, T.F. (2014). Inhalable microorganisms in Beijing's $\mathrm{PM}_{2.5}$ and $\mathrm{PM}_{10}$ pollutants during a severe smog event. Environ. Sci. Technol. 48: 1499-1507.

Cao, J.J., Shen, Z.X., Chow, J.C., Watson, J.G., Lee, S.C., Tie, X.X. and Han, Y.M. (2012). Winter and summer $\mathrm{PM}_{2.5}$ chemical compositions in fourteen Chinese Cities. J. Air Waste Manage. Assoc. 6: 1214-1226.

Chen, L.W.A. and Cao, J.J. (2018). $\mathrm{PM}_{2.5}$ source apportionment using a hybrid environmental receptor model. Environ. Sci. Technol. 52: 6357-6369.

Chen, L.W.A., Zhang, M., Liu, T., Fortier, K., Chow, J.C., Kolberg, R., Cao, J.J., Lin, G., Patel, T.Y., Cruz, P., Buttner, M.P. and Watson, J.G. (2019). Evaluation of epifluorescence methods for quantifying bioaerosols in fine and coarse particulate air pollution. Atmos. Environ. Submitted.

Chi, M.C. and Li, C.S. (2007). Fluorochrome in monitoring atmospheric bioaerosols and correlations with meteorological factors and air pollutants. Aerosol Sci. Technol. 41: 672-678.

Chow, J.C., Yang, X.F., Wang, X.L., Kohl, S.D., Hurbain, P.R., Chen, L.W.A. and Watson, J.G. (2015). Characterization of ambient $\mathrm{PM}_{10}$ bioaerosols in a California agricultural town. Aerosol Air Qual. Res. 15: 1433-1447.

Cox, C.S. and Wathes, C.M. (1995). Bioaerosol handbook. Lewis Publishers, Boca Raton, FL, USA.

Després, V., Huffman, J.A., Burrows, S.M., Hoose, C., Safatov, A., Buryak, G., Fröhlich-Nowoisky, J., Elbert, W., Andreae, M., Poeschl, U. and Jaenicke, R. (2012).
Primary biological aerosol particles in the atmosphere: A review. Tellus B 64: 15598.

Dong, L.J., Qi, J.H., Shao, C.C., Zhong, X., Gao, D.M., Cao, W.W., Gao, J.W., Bai, R., Long, G.Y. and Chu, C.C. (2016). Concentration and size distribution of total airborne microbes in hazy and foggy weather. Sci. Total Environ. 541: 1011-1018.

Douwes, J., Thorne, P., Pearce, N. and Heederik, D. (2003). Bioaerosol health effects and exposure assessment: Progress and prospects. Ann. Occup. Hyg. 47: 187-200.

Edgerton, E.S., Casuccio, G.S., Saylor, R.D., Lersch, T.L., Hartsell, B.E., Jansen, J.J. and Hansen, D.A. (2009). Measurements of $\mathrm{OC}$ and $\mathrm{EC}$ in coarse particulate matter in the southeastern United States. J. Air Waste Manage. Assoc. 59: 78-90.

Fröhlich-Nowoisky, J., Kampf, C.J., Weber, B., Huffman, J.A., Pöhlker, C., Andreae, M.O., Lang-Yona, N., Burrows, S.M., Gunthe, S.S., Elbert, W. and Su, H. (2016). Bioaerosols in the Earth system: Climate, health, and ecosystem interactions. Atmos. Res. 182: 346-376.

Fu, H.B. and Chen, J.M. (2017). Formation, features and controlling strategies of severe haze-fog pollutions in China. Sci. Total Environ. 578: 121-138.

Gao, M., Jia, R.Z., Qiu, T.L., Han, M.L., Song, Y. and Wang, X.M. (2015). Seasonal size distribution of airborne culturable bacteria and fungi and preliminary estimation of their deposition in human lungs during non-haze and haze days. Atmos. Environ. 118: 203-210.

Griffin, D.W. (2007). Atmospheric movement of microorganisms in clouds of desert dust and implications for human health. Clin. Microbiol. Rev. 20: 459-477.

Group, A.E. (2004). New Directions: The role of bioaerosols in atmospheric chemistry and physics. Atmos. Environ. 38: 1231-1232.

Haas, D., Galler, H., Luxner, J., Zarfel, G., Buzina, W., Friedl, H., Marth, E., Habib, J. and Reinthaler, F.F. (2013). The concentrations of culturable microorganisms in relation to particulate matter in urban air. Atmos. Environ. 65: 215-222.

Hallar, A., Chirokova, G., McCubbin, I., Painter, T.H., Wiedinmyer, C. and Dodson, C. (2011). Atmospheric bioaerosols transported via dust storms in the western United States. Geophys. Res. Lett. 38: L17801.

Hara, K. and Zhang, D.Z. (2012). Bacterial abundance and viability in long-range transported dust. Atmos. Environ. 47: 20-25.

Hauspie, R.C. and Pagezy, H. (2002). The contribution of bacteria and fungal spores to the organic carbon content of cloud water, precipitation and aerosols. Atmos. Res. 64: 109-119.

Heidi, B., Heinrich, G., Regina, H., Anne, K. Georg, R., Franziska, Z. and Hans, P. (2003). Airborne bacteria as cloud condensation nuclei. J. Geophys. Res. 108: 19191964.

Henry, R.C., Lewis, C.W., Hopke, P.K. and Williamson, H.J. (1984). Review of receptor model fundamentals. Atmos. Environ. 18: 1507-1515.

Huang, H.L., Lee, M.K., and Shih, H.W. (2017). Assessment of indoor bioaerosols in public spaces by 
real-time measured airborne particles. Aerosol Air Qual. Res. 17: 2276-2288.

Huffman, J.A., Treutlein, B. and Pöschl, U. (2010). Fluorescent biological aerosol particle concentrations and size distributions measured with an Ultraviolet Aerodynamic Particle Sizer (UV-APS) in Central Europe. Atmos. Chem. Phys. 10: 3215-3233.

Huffman, J.A., Prenni, A.J., DeMott, P.J., Pöhlker, C., Mason, R.H., Robinson, N.H., Fröhlich-Nowoisky, J., Tobo, Y., Després, V.R., Garcia, E. and Gochis, D.J. (2013). High concentrations of biological aerosol particles and ice nuclei during and after rain. Atmos. Chem. Phys. 13: 6151-6164.

Jaenicke, R. (2005). Abundance of cellular material and proteins in the atmosphere. Science 308: 73.

Jeon, E.M., Kim, H.J., Jung, K., Kim, J.H., Kim, M.Y., Kim, Y.P. and Ka, J.O. (2011). Impact of Asian dust events on airborne bacterial community assessed by molecular analyses. Atmos. Environ. 45: 4313-4321.

Johnson, D.L., Pearce, T.A. and Esmen, N.A. (1999). The effect of phosphate buffer on aerosol size distribution of nebulized Bacillus subtilis and Pseudomonas fluorescens bacteria. Aerosol Sci. Technol. 30: 202-210.

Kang, S.M., Heo, K.J. and Lee, B.U. (2015). Why does rain increase the concentrations of environmental bioaerosols during monsoon. Aerosol Air Qual. Res. 15: 2320-2324.

Li, C.S. and Huang, T.Y. (2006). Fluorochrome in monitoring indoor bioaerosols. Aerosol Sci. Technol. 40: 237-241.

Li, M.F., Qi, J.H., Zhang, H.D., Huang, S., Li, L. and Gao, D.M. (2011). Concentration and size distribution of bioaerosols in an outdoor environment in the Qingdao coastal region. Sci. Total Environ. 409: 3812-3819.

Li, Y.P., Fu, H.L., Wang, W., Liu, J., Meng, Q.L. and Wang, W.K. (2015). Characteristics of bacterial and fungal aerosols during the autumn haze days in Xi'an, China. Atmos. Environ. 122: 439-447.

Li, Y.P., Lu, R., Li, W.X., Xie, Z.S. and Song, Y. (2017). Concentrations and size distributions of viable bioaerosols under various weather conditions in a typical semiarid city of Northwest China. J. Aerosol Sci. 106: 83-92.

Liu, H.X., Zheng, J.R., Qu, C.K., Zhang, J.Q., Wang, Y.K., Zhan, C.L., Yao, R.Z. and Cao, J.J. (2017). Characteristics and source analysis of water-soluble inorganic ions in $\mathrm{PM}_{10}$ in a typical mining city, Central China. Atmosphere 8: 74.

Marty, A.N., DeLeon-Rodriguez, N., Waters, S., Ziemba, L., Anderson, B., Bergin, M., Konstantinidis, K. and Nenes, A. (2017). Understanding the link between meteorology and speciated abundance of bioaerosols in an urban environment using colocated flow cytometry and real-time autofluorescence measurements. $19^{\text {th }} \mathrm{EGU}$ General Assembly, EGU2017, proceedings from the conference held 23-28 April, 2017 in Vienna, Austria, p. 9555 .

Masiello, C.A. (2004). New directions in black carbon organic geochemistry. Mar. Chem. 92: 201-213.

Matthias-Maser, S. and Jaenicke, R. (2000). The size distribution of primary biological aerosol particles in the multiphase atmosphere. Aerobiologia 16: 207-210.

Mayol, E., Jiménez, M.A., Herndl, G.J., Duarte, C.M. and Arrieta, J.M. (2014). Resolving the abundance and airsea fluxes of airborne microorganisms in the North Atlantic Ocean. Front. Microbiol. 5: 557.

Pan, Y.L. (2015). Detection and characterization of biological and other organic-carbon aerosol particles in atmosphere using fluorescence. J. Quant. Spectrosc. Radiat. Transfer 150: 12-35.

Perrino, C. and Marcovecchio, F. (2016). A new method for assessing the contribution of primary biological atmospheric particles to the mass concentration of the atmospheric aerosol. Environ. Int. 87: 108-115.

Porter, K.G. and Feig, Y.S. (1980). The use of DAPI for identifying and counting aquatic microflora. Limnol. Oceanogr. 25: 943-948.

Prussin, A.J. II, Garcia, E.B. and Marr, L.C. (2015). Total concentrations of virus and bacteria in indoor and outdoor air. Environ. Sci. Technol. Lett. 2: 84-88.

Rathnayake, C.M., Metwali, N., Jayarathne, T., Kettler, J., Huang, Y., Thorne, P.S., O'Shaughnessy, P.T. and Stone, E.A. (2017). Influence of rain on the abundance of bioaerosols in fine and coarse particles. Atmos. Chem. Phys. 17: 2459-2475.

Rosenfeld, D., Lohmann, U., Raga, G.B., O’Dowd, C.D., Kulmala, M., Fuzzi, S., Reissell, A. and Andreae, M.O. (2008). Flood or drought: How do aerosols affect precipitation? Science 321: 1309-131.

Saari, S., Niemi, J.V., Rönkkö, T., Kuuluvainen, H., Järvinen, A., Pirjola, L., Aurela, M., Hillamo, R. and Keskinen, J. (2015). Seasonal and diurnal variations of fluorescent bioaerosol concentration and size distribution in the urban environment. Aerosol Air Qual. Res. 15: $572-581$.

Seo, I., Jha, B.K., Lim, J.G., Suh, S.I., Suh, M.H. and Baek, W.K. (2014). Identification of lysosomotropic compounds based on the distribution and size of lysosomes. Biochem. Biophys. Res. Commun. 450: 189-194.

Tong, Y. and Lighthart, B. (1999). Diurnal distribution of total and culturable atmospheric bacteria at a rural site. Aerosol Sci. Technol. 30: 246-254.

Watson, J.G., Chen, L.W.A., Chow, J.C., Doraiswamy, P. and Lowenthal, D.H. (2008). Source apportionment: Findings from the US supersites program. J. Air Waste Manage. Assoc. 58: 265-288.

Watson, J.G., Chow, J.C., Chen, L.W.A., Engling, G. and Wang, X.L. (2016). Source apportionment: Principles and methods. In Airborne particulate matter: Sources, atmospheric processes and health, Harrison, R.M., Hester, R.E. and Querol, X. (Eds.), The Royal Society of Chemistry, London, UK, pp. 72-125.

Wei, K., Zou, Z.L., Zheng, Y.H., Li, J., Shen, F.X., Wu, C.Y., Wu, Y.S., Hu, M. and Yao, M.S. (2016). Ambient bioaerosol particle dynamics observed during haze and sunny days in Beijing. Sci. Total Environ. 550: 751-759.

Xie, C.Q., Shen, F.X. and Yao, M.S. (2011). A novel method for measuring the charge distribution of airborne microbes. Aerobiologia 27: 135-145. 
Xie, Z.S., Li, Y.P., Lu, R., Li, W.X., Fan, C.L., Liu, P.X., Wang, J.L. and Wang, W.K. (2018). Characteristics of total airborne microbes at various air quality levels. $J$. Aerosol Sci. 116: 57-65.

Yeo, H.G. and Kim, J.H. (2002). SPM and fungal spores in the ambient air of west Korea during the Asian dust (Yellow sand) period. Atmos. Environ. 36: 5437-5442.

Zack, G.W., Rogers, W.E. and Latt, S.A. (1977). Automatic measurement of sister chromatid exchange frequency. J. Histochem. Cytochem. 25: 741-753.

Zhai, Y., Li, X., Wang, T., Wang, B., Li, C. and Zeng, G. (2018). A review on airborne microorganisms in particulate matters: Composition, characteristics and influence factors. Environ. Int. 113: 74-90.

Zhan, C.L., Zhang, J.Q., Zheng, J.R., Yao, R.Z., Wang, P., Liu, H.X., Xiao, W.S., Liu, X.L. and Cao, J.J. (2017). Characterization of carbonaceous fractions in $\mathrm{PM}_{2.5}$ and $\mathrm{PM}_{10}$ over a typical industrial city in central China. Environ. Sci. Pollut. Res. doi: 10.1007/s11356-017-9970-9.

Received for review, November 23, 2018

Revised, January 14, 2019 Accepted, January 15, 2019 